\title{
УАК 336.77:330.567.22
}

B. М. Харабара, к.е.н., дочент кафедри фінансів і кредиту, Чернівецький начіональний університет імені Юріл Федьковича, м. Чернівиі, Украӥна

ORSID ID: 0000-0002-8555-6440

P.I.Грешко, к.е.н., доцент кафедри фінансів ікредиту, Чернівецький начіональний університет імені Юріл Федьковича, м. Чернівиі, Украйна

ORSID ID: 0000-0003-3054-356X

DOI: $10.32702 / 2306-6806.2019 .4 .52$

\section{КРЕАИТУВАННЯ СПОЖИВЧИХ ПОТРЕБ НАСЕАЕННЯ ТА РОЗВИТОК ІНФРАСТРУКТУРИ РИНКУ ФІНАНСОВИХ ПОСАУГ}

\author{
V. Kharabara, \\ PhD in Economics, Associate Professor, Chernivtsi National Fedkovych University \\ R. Greshko, \\ PhD in Economics, Associate Professor, Chernivtsi National Fedkovych University
}

\section{CREDITING OF CONSUMER NEEDS OF POPULATION AND DEVELOPMENT OF INFRASTRUCTURE OF THE FINANCIAL SERVICES MARKET}

Публікацію присвячено аналізу сучасного станУ розвиткУ ринку фінансових ПослуГ в Украйні. Проведено аналіз публікацій, що присвячені проблематиці функціонування ринку фінансових послуг в Україні. В статті розкриті поняття "ринок споживчого кредитування" та "інфраструктура ринку споживчого кредитування"; проаналізовано стан інституційного наповнення інфраструктури ринку споживчого кредитування, визначено, що на ринку фінансових послуг найбільшу питому вагу мають учасники, які спеціаАізуються на певних фінансових послугах. У АосліАженні приділено основнУ Увагу таким проблемам, а саме: якості кредитів на споживчі потреби населення; проблемній заборгованості за кредитами на споживчі потреби; ризикам у банків-лідерів ринкукредитування; переважання схильності населення до отримання кредитів над схильністю до заощаджень у банківській системі; розширенню кАієнтської бази банків; спрощення процедури надання кредитів; посиленню конкуренції на ринку кредитування споживчих потреб населення. На основі дослідження автори пропонують основні напрями розвитку ринку фінансових послуг: розробка нормативно-правових актів, спрямованих на якісний розвиток на інфраструктури фінансовому ринку; Удосконалення, на основі співробітництва з бюро кредитних історій, автоматизованих Скорингових систем, що дозволить викАючити вПлив суб'єктивного чинника і делегувати право ухвалення кредитного рішення на рівень кредитного інспектора, який оцінюватиме якість позичальника за формальними задокументованими ознаками і прийматиме рішення на основі чітко сформуАьованих критеріїв; моніторинг, збір і обробку статистичної інформації про результати запроваджених "кредитних експериментів" і коригування скорингової модеді на рівні підрозділу фінансово-кредитної установи, до компетенції якого належать питання ризик-менеджменту; застосування процентних ставок, які, разом із економічним капіталом, повинні покривати певний "граничний" або акцептуємий рівень втрат, що є предметом прийняття рішень на рівні топ-менеджменту фінансово-кредитної установи; запропоновано організаційно-економічний механізм дї посередницьких структур, що дозволить забезпечити довіру населення.

The publication is devoted to the analysis of the current state of development of the financial services market in Ukraine. The analysis of publications devoted to the problems of functioning of the financial services market in Ukraine is carried out. The article describes the concept of "consumer lending market" and "consumer lending market infrastructure"; the state of institutional filling of the consumer lending infrastructure infrastructure was analyzed, it was determined that participants in the financial services market who are specialized in certain financial services have the largest share. The study focuses on the following issues, namely: the quality of loans for consumer needs; bad debts on loans for consumer needs; risks from the leading banks of the lending market; the prevalence of the population's propensity to obtain loans over the propensity to save in the banking system; 
expansion of the customer base of banks; simplifying the procedure of granting loans; to increase competition in the consumer lending market. On the basis of the research, the authors propose the main directions of the development of the financial services market: the development of legal acts aimed at qualitative development of the financial market infrastructure; improving, on the basis of cooperation with the bureau of credit histories, automated scoring systems, which will eliminate the influence of the subjective factor and delegate the right to make a credit decision to the level of the credit inspector, which will assess the quality of the borrower on formal documented grounds and make a decision based on well-defined criteria; monitoring, collecting and processing of statistical information on the results of implemented "credit experiments"and adjusting the scoring model at the level of a unit of a financial and credit institution, whose competence includes risk management issues; the application of interest rates that, together with economic capital, should cover a certain "marginal"or acceptance level of losses that is the subject of decision-making at the level of top management of the financial and credit institution; The organizational and economic mechanism of the intermediary structures action is proposed, which will ensure the trust of the population.

Ключові слова: фінансові послуги, споживчий кредит, інфраструктура ринку, скоринг, бюро кредитних icmopiü.

Key words: financial services, consumer credit, market infrastructure, scoring, bureau of credit bistories.

\section{ПОСТАНОВКА ПРОБЛЕМИ}

Інфраструктура ринку фінансових послуг забезпечує можливість реалізації економічних інтересів суб'єктів господарювання, сприяє координації їх економічних дій, допомагає інтегруватись у світовий економічний та фінансовий простір.

Інфраструктура внутрішньої системи ринку фінансових послуг сприяє формуванню попиту на фінансові послуги, зростанню обсягів їх реалізації, розширенню та модифікації асортименту, модифікації ринку та поведінки споживачів. Ао внутрішньої системи ринку фінансових послуг належать фінансовий і кадровий потенціал фінансово-кредитних установ, наявність існуючих і потенційних клієнтів, рівень їх довіри, ефективність співпраці з фінансовими інститутами, якість маркетингової діяльності та ефективність реалізації стратегічних рішень.

\section{ЛІТЕРАТУРНИЙ ОГЛЯД}

Проблеми розвитку кредитування споживчих потреб населення на розвиток інфраструктури ринку фінансових послуг знайшли відображення в працях зарубіжних та вітчизняних науковців: М. Ауріємма, К. Барлтропа, Р. Гоні,Аж. Аюсенбері, Р. Коттера, Т. Майєра, К. Редхеда, 3. Васильченко, О. Васюренко, В. Кравченко, О. Кириченко, І. Аютий, В. Міщенко, С. Науменкова, Г. Панова, $\Lambda$. Примостка, $\Lambda$. Романенко, О. Солодка, О. Ятченко.

\section{META CTATTI}

Метою статті є вплив кредитування споживчих потреб населення на розвиток інфраструктури ринку фінансових послуг.

\section{ОСНОВНІ МАТЕРІАЛИ ДОСЛІДЖЕННЯ}

Рівень конкуренції між банками і кредитними спілками значно посилив розвиток ринку кредитування споживчих потреб населення. Кредитні спілки, на відміну від інших суб'єктів фінансово-кредитного ринку, не є господарчими товариствами, а виступають, дефакто, фінансовими кооперативами. Ао діяльності кредитних спілок не можна застосувати поняття "клієнт" і "власник", оскільки всі члени кредитної спілки є одночасно і клієнтами, і власниками.

Аля того, щоб скористатися послугами кредитної спілки (відкрити депозитний рахунок або отримати кре- дит), відповідно до Закону "Про кредитні спілки", необхідно стати їі членом. Аля цього необхідно подати заяву і сплатити пайовий і вступний внески, розміри яких складають від 1 грн до 500 грн, у залежності від рішення кредитної спілки. Слід зазначити, що кредитні спілки створюються за ознакою спільної роботи її членів (наприклад, трудовий колектив), належності до однієї профспілки, суспільної або релігійної організації або за регіональною ознакою. Тому кількість членів кредитної спілки обмежена дією обраної ознаки. Кожен член кредитної спілки має один голос на загальних зборах їі членів.

Особливості діяльності кредитних спілок накладають відбиток на процес кредитування ними споживчих потреб населення. Потенційні члени кредитних спілок не можуть розраховувати на кредитування купівлі житла, що обумовлене дією наступних факторів: по-перше, у кредитних спілок, на відміну відінших фінансово-кредитних установ, практично єдиним джерелом ресурсів $€$ депозити фізичних осіб, у той час як комерційні банки мають альтернативні варіанти залучення засобів і отримання доходів; по-друге, жодна кредитна спілка не має можливості отримати ліцензію на здійснення валютних операцій, тому кредити можуть надаватися лише в національній валюті; по-третє, всі ресурси, що залучаються кредитними спілками, як правило, короткострокові (до 1 року). Таким чином, ресурси кредитних спілок $є$ дорожчими, а отже, вартість кредитів на споживчі потреби населення є більшою, ніж вартість кредитних продуктів комерційних банків. Крім того, у випадку банкрутства комерційного банку Фонд гарантування вкладів фізичних осіб зобов'язується повернути частину засобів за вкладами, включаючи відсотки [8]. Проте на діяльність кредитних спілок зазначена гарантія не поширюється, що збільшує ризики кредитування споживчих потреб населення.

На наш погляд, позитивними аспектами діяльності кредитних спілок у розрізі кредитування споживчих потреб населення $є$ швидке оформлення кредитних угод, менша кількість необхідних документів, лояльні вимоги до фінансового стану позичальника, відсутність прихованих комісій. Кредитні спілки реалізують більш гнучкий підхід до позичальника: у випадку тимчасових фінансових проблем, пеня за прострочення виплат за кредитом за згодою сторін не стягується. Оскільки кредитні спілки мають обмежену кількість членів $(50$ і 
більш), процес управління проблемною заборгованістю і індивідуальна робота з боржниками $є$ більш ефективною, ніж у комерційних банках.

Слід зазначити, що активна пропозиція комерційних банків щодо надання експрес-кредитів і оформлення кредитних карток визначила для кредитних спілок нерівні ринкові умови. Ефективна процентна ставка банків за експрес-кредитами у 2016-2017 роках складала в середньому $70-80 \%$, у той час як, у кредитних спілок вона коливалась в межах 70-100\% [8]. Зазначена обставина стимулювала кредитні спілки до освоєння нових сегментів ринку кредитування споживчих потреб населення, зокрема, кредитування автомобілів, які були у використанні.

Розвиток ринку кредитування споживчих потреб населення сприяв істотному розширенню регіональних мереж комерційних банків, що мало наслідком підвищення рівня життя в регіонах.

У 2016-2017 роках суттєво зросла конкуренція між українськими банками в сегменті Private banking (індивідуальне банківське обслуговування значних приватних клієнтів і їх родин - VIP-клієнтів). За даними Асоціації українських банків, 5-10\% приватних VIPклієнтів забезпечують комерційному банку 70-80\% доходів у сегменті обслуговування фізичних осіб. У рамках ексклюзивного обслуговування VIP-клієнту надається персональний менеджер, що перебуває на зв'язку 24 години на добу. Ексклюзивними послугами, які комерційні банки почали пропонувати VIP-клієнтам, $є$ кредитування купівлі ексклюзивних автомобілів, яхт, витворів мистецтва, нерухомості, послуги особистих фінансових радників. У всіх банків $є$ перелік вимог (так званий "вхідний квиток") для таких клієнтів: розмір пасивів у банку, сума щомісячного доходу, використання карти преміального рівня та інші. У порівнянні зі світовою практикою, український "вхідний квиток" відносно недорогий. Середньорічний дохід клієнта Private Banking в Україні починається з суми, близької до 1 мільйона гривень на рік. Тоді як у світі послуги Private Banking доступні лише людям 3 мільйонними статками у твердих валютах, в Україні отримати високий рівень обслуговування можуть представники середнього класу. Основними можливостями для розвитку послуг Private Banking y $2017-2018$ рр. експерти називають зняття валютних обмежень, збільшення кількості клієнтів за рахунок скорочення кількості банків у країні та відновлення роботи з фондовими ринками.

На наш погляд, інтенсивний розвиток кредитування споживчих потреб населення сприяв появі якісно нових конкурентів комерційних банків на ринку кредитування - соціальних мереж.

За даними дослідження консалтингової компанії Gartner, платформи соціального банкінгу - мережі міжперсонального кредитування (Peer-to-Peer (P2P) Lending) Zopa i Prosper - ще на початку 2010 року контролювали $10 \%$ світового ринку роздрібного кредитування, а на даний момент цей відсоток $є$ значно вищим.

Експерти Gartner визначають "соціальний банкінг" (social banking) як поєднання трендів, серед яких екопрактика, соціальне підприємництво, персональне кредитування і фінансове планування, за допомогою соціальних мереж і банківських продуктів і послуг.

На наш погляд, платформи соціального банкінгу агресивно проникають у сферу банківських і інвестиційних послуг, особливо це стосується кредитного і платіжного секторів. Такі платформи персонального кредитування, як Zopa, Prosper i Lending Club, за останні роки отримали значні вкладення від венчурних інвесторів: американська компанія Prosper - \$40 млн дол. США, а 11 британський конкурент Zора - близько \$34 млн дол. США. Ще десять років назад компанія Virgin Group відомого Річарда Бренсона (Richard Branson) придбала контрольний пакет акцій Circle Lending - організації, що надає послуги кредитного адміністрування і спеціалі- зується на управлінні кредитами на споживчі потреби населення. Таким чином, ризикові інвестиції Virgin Group підтверджують зростаючу перевагу даних послуг і збільшення споживчого інтересу до кредитної сфери.

Більшість споживачів проводять певний час у соціальних мережах, які поступово стають складовою процесу придбання продуктів і послуг. Першими запровадили сервісні платформи персонального кредитування США і країни Західної Європи, оскільки там існує розвинений ринок банківських продуктів і послуг і впроваджена широкосмужна мережа. Ао того ж, ці країни мають значний потенціал для поширення бездротових комунікаційних систем.

На нашу думку, комерційним банкам України доцільно впроваджувати західний досвід соціального банкінгу лише за умови розробки чіткої стратегії, основою якої є соціальне забезпечення як альтернатива традиційній комерційній віддачі. Слід зауважити, що сучасний стан розвитку кредитування споживчих потреб населення України обумовлює розгляд можливості співробітництва вітчизняних комерційних банків із фінансовими соціальними мережами з метою оптимізації процесінгу транзакцій і управління ризиками. Так, кредитні спілки США реалізували даний підхід, уклавши угоди із мережею міжперсонального кредитування Zора і пропонуючи міжперсональні позики перспективним позичальникам. Крім того, вважаємо, що для вітчизняних комерційних банків доцільними є інвестиції в поведінковий аналіз і прогнозне програмне забезпечення як інструменти моделювання змін у споживчій поведінці існуючих і потенційних клієнтів.

Розвиток банківського роздрібу, тобто наявність попиту на кредити на споживчі потреби населення із ефективною процентною ставкою від $35 \%$ до $100 \%$ річних із одночасною низькою насиченістю українського ринку споживчого кредитування, сприяв підвищенню привабливості вітчизняного ринку кредитування споживчих потреб населення для іноземних банків і поглинанню українських фінансових установ.

За даними Національного банку України, частка іноземного капіталу в банківській системі України за останні п'ять років постійно змінювалася і станом 01.01.2017 р. становила 54,7\%, що є найбільшим показником за останні 15 років. Окремо слід зазначити, що банківські установи з іноземним капіталом виявилися більш стійкими в кризовий період, про що свідчить випередження темпу падіння кількості банків, що мають ліцензію, порівняно з темпом падіння кількості діючих банків з іноземним капіталом. Станом на 01.01.2017 р. у банківській системі України присутній та функціонує капітал таких банківських груп: шведської SEB Group (ПАТ "СЕБ Корпоративний Банк"); американського холдингу Citigroup (ПАТ "Сітібанк"); французьких груп Credit Agricole Group (ПАТ "Креді Агріколь Банк") та BNP Paribas (AT "Укрсиббанк"); італійської групи Unicredit (ПАТ "Укрсоцбанк"); німецького банку Deutsche Bank (ПАТ "Аойче Банк АРУ"); польського банку PKO Bank Polski (ПАТ "Кредобанк"); російського банку "Сбербанк" та ін. [2].

На нашу думку, основна ідея ринкової стратегія більшості іноземних банківських груп полягає в об'єАнанні придбаних активів у одній юридичній особі і розвитку не лише мережі продажів, а і мережі обслуговування. Крім того, поточна фінансова криза серйозно похитнула фінансову стійкість, кредитоспроможність та платоспроможність вітчизняних банків, чим скористалися дочірні банки іноземних материнських компаній, посиливши свою конкурентоспроможність шляхом додаткової капіталізації.

Результати проведеного дослідження дали змогу виявити сучасних лідерів із-поміж 25 банків іноземних банківських груп: АТ "Райффайзен Банк Аваль", ПАТ "Сітібанк", ПАТ "КредіАгріколь Банк" та ПАТ "ІНГ Банк Україна"; найменш надійні та найменш 
дієздатні банки: ПАТ "Промінвестбанк", ПАТ "ВТБ Банк", ПАТ "АльтБанк" та АТ "БМ Банк". Під час кризи банки іноземних банківських груп забезпечили фінансову стійкість банківської системи України завдяки збереженню внутрішньокорпоративного припливу дефіцитних капітальних і кредитних коштів. Населення більше довіряло банкам з іноземним капіталом, що проявилося в майже незмінному обсязі зобов'язань цих банків на відміну від вітчизняних [2].

Слід зазначити, що вихід на вітчизняний ринок кредитування іноземних банків, у деяких випадках, сприяв посиленню ринкових позицій вітчизняних банків. Так, посиленню ринкових позицій Приватбанку на ринку кредитування споживчих потреб населення сприяв продаж банків "Просто Кредит" i "Приватінвест" і одночасне впровадження інноваційної програми кредитування "Новий кредит", яка передбачала оформлення кредитних карток безпосередньо в торговельних закладах.

Узагальнюючи результати аналізу вітчизняного кредитного механізму забезпечення споживчих потреб населення, визначимо чотири форми забезпечення кредитів: застава; гарантія; поручительство; страхування кредитних ризиків. Попри високу надійність перших трьох зазначених форм забезпечення кредитів іх застосування іноді $є$ незручним, важкодоступним і невигідним для учасників кредитних відносин. За цих умов, найбільш доступною та надійною формою фінансового забезпечення інтересів кредиторів стає страхування, яке базується на визнанні ризику неплатежу чи неплатоспроможності позичальників, який формується у процесі кредитування. Але в сучасних умовах дана форма викликає найбільшу кількість непорозумінь, суперечок та дискусій.

Стосовно страхування кредитних ризиків у вітчизняному законодавстві виокремлено три види страхування: страхування кредитів; страхування відповідальності позичальника за непогашення кредиту; страхування виданих гарантій (порук) та прийнятих гарантій [3].

Сучасне вітчизняне законодавство [3] покладає на заставодавця обов'язок страхування нерухомих об'єктів та предметів іпотеки, переданих ним у заставу. Таке страхування має здійснюватися за рахунок коштів заставодавця у повній вартості заставного майна, але на користь заставодержателя. Разом із тим, при заставі рухомого майна, такий обов'язок покладається на заставодержателя. Він повинен страхувати предмет застави в обсязі його вартості та в інтересах заставодавця.

Сфера застосування застави постійно розширюється разом із введенням на ринок нових форм застав. Предметами застави є нерухомість, транспортні засоби, земельні ділянки. Банки спільно зі страховими компаніями розробляють і впроваджують механізм одержання кредиту під заставу сільськогосподарської продукції.

У разі делькредерної форми організації страхових відносин кредитори (банки) відіграють роль страхувальників і застрахованих одночасно, а тому страхові відносини обмежуються лише стосунками між двома сторонами - страховиком і страхувальником.

Аелькредерне страхування складається з двох груп страхових відносин: страхування товарних кредитів і страхування фінансових (грошових) кредитів. У першій групі страховий захист забезпечується як внутрішньому, так і зовнішньому (експортно-імпортному) товарообігу, який здійснюється на кредитній основі. Аругу групу делькредерного страхування становлять операції зі страхування фінансових кредитів, тобто переважно тієї частини споживчих кредитів та кредитів під інвестиційні потреби, яка надана у грошовій формі [11, с. 123-125].

Майновий інтерес кредитора може бути захищений шляхом страхового захисту платоспроможності його боржника. За цієї форми страхових відносин страхувальником $є$ позичальник, який, страхуючи свою платоспроможність, захищає інтереси кредитора. Водно- час страховик, страхуючи платоспроможність позичальника, надає гарантію кредиторові повернути борг. Отже, із правового боку, ця страхова операція є, по суті, наданням страховиком страхового гарантійного зобов'язання, яке для кредитора слугує заставою на випадок неповернення боргу. 3 огляду на це, у страховій теорії та практиці страхові відносини такого характеру мають назву заставних, або гарантійних [13, с. 59-62].

Економічний зміст страхової гарантії зводиться до того, що страховик замість отриманої невисокої страхової премії бере на себе (замість боржника) роль гаранта оплати його повної заборгованості у визначених термінах на користь застрахованого (бенефіціанта) цієї гарантії. Таким чином, страхування кредитів має на меті задоволення майнових потреб, які генеруються ризиком неповернення кредиту, через перерозподіл втрат між суб'єктами кредитно-страхових відносин, тобто фінансово-кредитною установою, боржником і страховою компанією.

Період пікового попиту на кредити на споживчі потреби населення завжди характеризується підвищеним інтересом банків до страхування таких кредитів. Проте, більшість страхових компаній неохоче погоджувалися на співробітництво із банками, не бажаючи перетворюватися на колекторські компанії.

Слід зазначити, що страхування кредитів є потенційно вигідним як для банків, так і для страхових компаній: банкіри таким чином вирішують питання проблемної заборгованості, а страховики - отримують стабільне джерело доходів на потенційно великому ринку.

На нашу думку, страхування кредитів $€$ досить конфліктним видом страхування. Банк, по суті, перекладає на страхову компанію функції колекторського центру, тобто відповідальність за повернення боргів. Страхова компанія стає заручником роботи служби безпеки і ризик-менеджерів банку. В цьому випадку рівень збитковості страхової компанії залежить від якості роботи банківської установи.

Таким чином, страхування кредитів $є$ інструментом очищення кредитного портфелю банку від проблемної заборгованості, тобто підвищення його якості. Тому банк, значну частку кредитного портфелю якого складають кредити на споживчі потреби населення, має можливість створити фєктивну страхову компанію, яка вчасно вилучить із балансу банку проблемні кредити і прийме їх на себе. Але, попри усі несприятливі фактори, що стримують розвиток страхування ризиків банків в Україні, за кордоном цей метод управління ризиками став одним із найефективніших, що дає підстави вважати страхування одним із найкращих засобів мінімізації ризиків. Страхування кредитних ризиків - це не лише запорука збільшення прибутку банку, але й покращення його іміджу, що також сприяє підвищенню фінансової стабільності і конкурентоспроможності на ринку. Страхування кредитних ризиків має велике значення для надання кредитних послуг. Механізми здійснення страхування кредитів розроблені та в змозі ефективно функціонувати, але їх необхідно вдосконалювати, з урахуванням особливостей економіки нашої країни. I, якщо стабілізувати економічну ситуацію в країні та дотримуватися вимог чинного законодавства, страхування кредитних ризиків матиме величезний потенціал і буде дуже прибутковою справою [12].

На наш погляд, вплив кредитування споживчих потреб населення позначився на розвитку якісної структури довгострокового партнерства фінансово-кредитних установ із торговельними мережами.

Останніми роками фінансово-кредитні установи, які мали намір збільшувати власні частки на ринку кредитування споживчих потреб населення, змушені були активно розвивати мережі надання та обслуговування кредитів. При цьому особливого значення набули ефективні скорингові системи та наявність колекторських компаній. Першу в Україні колекторську компанію Credit 
Collection Group заснував Аельта Банк.

Кредитори, яким не вдалося укласти угоди з торговельними мережами, практикували альтернативні способи кредитування споживчих потреб. Зазначимо, що в країнах Європи поширеним є надання кредитів на споживчі потреби через Інтернет і засоби телефонного зв'язку (direct-to-consumer credit), однак в Україні протягом останніх років активно надавали такі кредити лише ті фінансово-кредитні установи, які співробітничали з торговельними мережами [14, с. 158-160].

Різке збільшення неповернень роздрібних кредитів вимагає впровадження нових стандартів кредитування споживчих потреб населення. 3 цього приводу, доцільним для впровадження у вітчизняну практику кредитування є досвід країн-членів ЄС. Правила кредитування споживачів, передбачають посилення прозорості процесу кредитування, а саме: надання повної інформації для споживачів у всіх країнах-членах $Е С$ щодо таких параметрів кредитування як відсотки за споживчими кредитами, обсяги, кількість, частота виплат, комісії, штрафи тощо. Крім того, нова директива споживчого кредитування передбачала, що у випадку, якщо споживач бажає погасити кредит раніше терміну, передбаченого кредитною угодою, фінансово-кредитна установа має право накласти на нього штраф, який не перевищує $1 \%$ суми кредиту. Метою внесення змін у правила кредитування споживачів $є$ уніфікація і здешевлення споживчих кредитів, а також можливість для громадян країн-членів ЄС отримати споживчий кредит в банках будь-якої країни-члену ЄС.

Таким чином, вплив кредитування споживчих потреб населення на розвиток інфраструктури ринку фінансових послуг позначився на інституційних елементах інфраструктури ринку фінансових послуг, інформаційних системах фінансово-кредитних установ, інфраструктурі ринку страхових послуг. Розвиток ринку кредитування споживчих потреб населення: вплинув на розширення діяльності кредитних спілок, а саме: стимулював кредитні спілки до освоєння нових сегментів ринку кредитування, зокрема, кредитування автомобілів, які були у використанні; сприяв істотному розширенню регіональних мереж комерційних банків, що мало наслідком підвищення рівня життя в регіонах; призвів до суттєвого зростання конкуренції між українськими комерційними банками в сегменті Private banking; сприяв появі якісно нових конкурентів комерційних банків на ринку кредитування - соціальних мереж; посилив експансію іноземних фінансово-кредитних установ на вітчизняний ринок кредитування споживчих потреб населення; стимулював інтеграцію зусиль комерційних банків і страхових компаній у розвитку страхування кредитів, що має прояв у перерозподілі втрат між суб'єктами кредитно-страхових відносин, тобто фінансово-кредитною установою, боржником і страховою компанією, іє достатньо конфліктним видом страхування; позначився на розвитку якісної структури довгострокового партнерства фінансово-кредитних установ із торговельними мережами; актуалізував необхідність впровадження нових стандартів кредитування споживчих потреб населення; засвідчив доцільність впровадження в діяльність фінансово-кредитних установ комплексного підходу до оцінки ризиків кредитування споживчих потреб населення.

На нашу думку, доцільним є впровадження в діяльність фінансово-кредитних установ комплексного підходу до оцінки ризиків кредитування споживчих потреб населення, який має містити:

- удосконалення, на основі співробітництва з бюро кредитних історій, автоматизованих скорингових систем, що дозволить виключити вплив суб'єктивного чинника і делегувати право ухвалення кредитного рішення на рівень кредитного інспектора, який оцінюватиме якість позичальника за формальними задокументованими ознаками і прийматиме рішення на основі чітко сформульованих критеріїв;

- моніторинг, збір і обробку статистичної інформації про результати запроваджених "кредитних експериментів" і коригування скорингової моделі на рівні підрозділу фінансово-кредитної установи, до компетенції якого належать питання ризик-менеджменту;

- застосування процентних ставок, які, разом із економічним капіталом, повинні покривати певний "граничний" або акцептуємий рівень втрат, що є предметом прийняття рішень на рівні топ-менеджменту фінансово-кредитної установи. Зазначимо, що даний "граничний" рівень втрат є результатом інтегрованого управлінського рішення, при прийнятті якого слід врахувати не лише ставлення менеджменту до ризиків (у координатах "обережність" і "схильність до ризику"), а і умови ринкового оточення кредитора (конкурентні ринкові процентні ставки);

- підтримку адекватного власного капіталу кредитора, тобто дотримання принципу достатності рівня, так званого, економічного капіталу, який є визначеним буфером на випадок виникнення небажаних для кредитора втрат, що перевищують їх очікуваний рівень.

Запропоновані складові комплексного підходу до оцінки ризиків кредитування споживчих потреб населення вимагають уточнення сутності автоматизованої скорингової системи оцінки кредитних ризиків.

Слід зауважити, що співробітництво фінансово-кредитних установ із бюро кредитних історій також має визначені ризики. Аержавним органом, уповноваженим контролювати діяльність бюро кредитних історій, є Міністерство юстиції України, яке пропонує (проектом постанови) оцінювати ступінь ризику, пов'язаного зі збором, використанням і захистом інформації про позичальників.

Відповідно до Закону України "Про організацію формування і обігу кредитних історій", бюро кредитних історій отримують необхідну інформацію про позичальників від банків, але лише за згодою позичальників. Разом із тим, за Законом, фінансово-кредитна установа може відмовитися надавати кредит, якщо позичальник не погоджується, щоб його персональні дані було переадресовано до бюро кредитних історій. Проте на практиці випадки таких відмовлень зустрічаються надто рідко, частішими є випадки занесення у базу даних бюро кредитних історій недостовірної інформації про позичальника не на його користь (наприклад, визначення позичальника як сумнівного, хоча насправді він таким не $є)$. Отже, незважаючи на існування рамкового закону, правове регулювання даного питання в Україні досить слабке.

За Законом, для формування кредитних історій бюро кредитних історій мають право використовувати інформацію державних реєстрів, інформацію баз даних публічного користування, інших, відкритих для загального користування джерел, за винятком інформації, що містить державну таємницю. Першою інстанцією запобігання ризиків є сам позичальник, який може перевірити власні особисті дані i, у разі потреби, опротестувати недостовірну інформацію, надавши необхідні коментарі з цього приводу.

На сьогоднішній день бюро кредитних історій використовують стандартні методи захисту інформації, аналогічні тим, що застосовуються в електронній платіжній системі WebMoney та інших електронних ресурсах, через які проходить великий обсяг інформації, а саме: SSLпротокол і внутрішній захист, тобто сервер, до якого має доступ обмежене коло співробітників.

\section{ВИСНОВКИ З ПРОВЕДЕНОГО ДОСЛІДЖЕННЯ}

Результати проведеного дослідження дають підстави визначити причини зростання ступеню ризиків кредитування споживчих потреб населення, а саме: погіршення якості кредитів на споживчі потреби населен- 
ня; істотне перевищення проблемної заборгованості за кредитами на споживчі потреби над проблемною заборгованістю за іншими видами кредитів; концентрація ризиків у банках-лідерах ринку кредитування; переважання схильності населення до отримання кредитів над схильністю до заощаджень у банківській системі; розширення клієнтської бази комерційних банків за рахунок зниження вимог до позичальників; спрощення процедури надання кредитів з метою зниження рівня витрат; посилення конкуренції на ринку кредитування споживчих потреб населення.

Наслідками зростання ризиків кредитування споживчих потреб населення є: надвисокі процентні ставки за кредитами як премія за ризик; зростання обсягів проблемної заборгованості при одночасному збільшенні обсягів реалізації кредитних продуктів і послуг; виникнення фінансових проблем у банків-лідерів ринку кредитування споживчих потреб.

На нашу думку, з метою мінімізації прояву наслідків зростання ризиків кредитування споживчих потреб населення, доцільною $є$ реалізація наступних заходів: посилення вимог до позичальників через жорстку процедуру надання кредитів на споживчі потреби; спрощення процедури стягнення заставного майна несумлінного боржника; створення ефективної системи бюро кредитних історій; створення ефективної системи взаємодії фінансово-кредитних установ, бюро кредитних історій, колекторських і страхових компаній.

\section{Мітература:}

1. Бондаренко Н.В. Сучасний стан кредитування комерційними банками фізичних осіб в Україні / Н.В. Бондаренко // Збірник наукових праць Уманського національного університету садівництва. - 2017. - Вип. 85. - C. 242-248.

2. Гірченко Т.А., Стороженко О.О. Шейко О.П. Аналіз сучасного стану та перспективи розвитку банків іноземних банківських груп в Україні [Електронний ресурс]. - Режим доступу: http://global-national.in.ua/ archive/16-2017/132.pdf

3. Закон України "Про страхування" від 07.03.96 pоку № $85 / 96$-ВР.

4. Закон України "Про споживче кредитування"від 15.11.2016 року № 1734-VIII-BP.

5. Міщенко B.I. Сучасна практика споживчого кредитування в Україні / В.І. Міщенко, О.А. Шаповал // Вісник Національного банку України. - 2013. — № 11. - С. 3-9.

6. Осадчий Є. Сучасний стан та проблеми банківського споживчого кредитування в Україні / Є. Осадчий / / Ринок цінних паперів України. - 2013. - № 11-12. - C. $97-102$.

7. Основні показники діяльності банків [Електронний ресурс]. - Режим доступу: http://www.bank.gov.ua.

8. Офіційний сайт Всеукраїнської Асоціації Кредитних Спілок [Електронний ресурс]. - Режим доступу: http://www.uacu.org.ua

9. Офіційний сайт Національного банку України [Електронний ресурс]. - Режим доступу: http:// www.bank.gov.ua

10. Офіційний сайт Українського бюро кредитних історій [Електронний ресурс].-Режим доступу: https://ubki.ua

11. Сабодаш Р. Страхування кредитних ризиків спосіб забезпечення виконання зобов'язань чи їх окремий вид [Електронний ресурс]. - Режим доступу: https:/ /dokupdf.com/download/ - 2005-11-c-123-125_5a02b8a6d6 4ab2b9bdd388c4_pdf.

12. Романько Г.А. Страхування кредитних ризиків в України [Електронний ресурс]. - Режим доступу: http:/ /molodyvcheny.in.ua/files/journal/2016/1/58.pdf

13. Сабодаш Р. Співвідношення національного та європейського законодавства в сфері страхування кредитних ризиків [Електронний ресурс]. - Режим доступу: http://www.academia.edu/24823236

14. Чайковський Я. І. Аналіз сучасного стану та пер- спективи розвитку банківського споживчого кредитування в Україні / Ярослав Іванович Чайковський / Економічний аналіз: зб. наук. праць / Тернопільський національний економічний університет; редкол.: О.В. Ярощук (голов. ред.) та ін. - Тернопіль: Видавничо-поліграфічний центр Тернопільського національного економічного університету "Економічна думка", 2017. - Т. 27. - № 1. - C. 156-163.

15. Шевалдіна В.Г. Сучасний стан кредитування населення в Україні / В.Г. Шевалдіна // Фінанси, облік і аудит. - 2013. - Вип. 1 (21). - С. 171-180.

16. Шейко О.П. Тенденції розвитку споживчого кредитування в Україні / О.П. Шейко // Вісник ОНУ імені Мечникова. - 2014. - Т. 19. Вип. 1/2. - С. 149-153.

\section{References:}

1. Bondarenko, N.V. (2017), "The current state of lending to commercial banks of individuals in Ukraine", Zbirnyk naukovykh prats' Umans'koho natsional'noho universytetu sadivnytstva, vol. 85 , pp. 242-248.

2. Hirchenko, T.D. Storozhenko, O.O. and Shejko, O.P. (2017), "Analysis of the current state and prospects of development of banks of foreign banking groups in Ukraine", available at: http://global-national.in.ua/archive/16-2017) 132.pdf (Accessed 15 March 2019).

3. Verkhovna Rada of Ukraine (1996), The Law of Ukraine "On Insurance", available at: https://zakon.rada.gov.ua/laws/show/en/85/96-\%D0\%B2\%D1\%80 (Accessed 15 March 2019).

4. Verkhovna Rada of Ukraine (2016), The Law of Ukraine "On consumer lending", available at: https:// March 2019).

5. Mischenko, V.I. and Shapoval, O.A. (2013), "Modern practice of consumer lending in Ukraine", Visnyk Natsional'noho banku Ukrainy, vol. 11, pp. 3-9.

6. Osadchyj, Ye. (2013), "The current state and problems of bank consumer lending in Ukraine", Rynok tsinnykh paperiv Ukrainy, vol. $11-12$, pp. 97-102.

7. National bank of Ukraine (2019), "Basic indicators of banks activity", available at: http://www.bank.gov.ua (Accessed 15 March 2019).

8. All-Ukrainian Association of Credit Unions (2019), available at: http:// www.uacu.org.ua (Accessed 15 March 2019).

9. National bank of Ukraine (2019), available at: http:/ /www.bank.gov.ua (Accessed 15 March 2019).

10. Ukrainian Bureau of Credit Histories (2019), available at: https://ubki.ua (Accessed 15 March 2019).

11. Sabodash, R. (2005), "Insurance of credit risks - a way to ensure fulfillment of obligations or their separate kind", available at: https://dokupdf.com/download/-200511-c-123-125-_5a02b8a6d6 4ab2b9bdd388c4_pdf (Accessed 15 March 2019).

12. Roman'ko, H.A. (2016), "Insurance of credit risks in Ukraine", available at: http://molodyvcheny.in.ua/files/ journal/2016/1/58.pdf (Accessed 15 March 2019).

13. Sabodash, R. (2006), "Value of national and European legislation in the field of credit risk insurance", available at: http://www.academia.edu/24823236 (Accessed 15 March 2019).

14. Chajkovs'kyj, Ya.I. (2017), "Analysis of the current state and prospects of development of bank consumer lending in Ukraine", Ekonomichnyj analiz: zb. nauk. prats' Ternopil's'koho natsional'noho ekonomichnoho universytetu, vol. 27, no.1, pp. 156-163.

15. Shevaldina, V.H. (2013), "The current state of lending to the population in Ukraine", Finansy, oblik i audyt, vol. 1 (21), pp. 171-180.

16. Shejko, O.P. (2014), "Trends in consumer lending in Ukraine", Visnyk ONU imeni Mechnykova, vol. 19, no. 1/ 2, pp. 149-153.

Стаття надійшла до редакиї 27.03.2019 р. 